\title{
Two New Leptospiral Serovars in the Hebdomadis Serogroup Isolated from Zimbabwe Cattle
}

\author{
SARA B. FERESU, ${ }^{1 *}$ HANS KORVER,${ }^{2}$ NATACHA RIQUELME, ${ }^{3}$ GUY BARANTON,${ }^{3}$ \\ AND CAROLE A. BOLIN ${ }^{4}$ \\ Department of Biological Sciences, University of Zimbabwe, Mount Pleasant, Harare, Zimbabwe ${ }^{1}$; N. H. Swellengrebel \\ Laboratory of Tropical Hygiene, The Royal Tropical Institute, 1105 AZ Amsterdam. The Netherlands ${ }^{2}$; Unite de \\ Bactériologie, Moléculaire et Médicale, Institut Pasteur, 75724 Paris Cedex 15, France ${ }^{3}$; and Leptospirosis \\ and Mycobacteriosis Research Unit, National Animal Disease Center, Agricultural Research \\ Service, U.S. Department of Agriculture, Ames, Iowa $50010^{4}$
}

\begin{abstract}
Four strains belonging to the genus Leptospira serogroup Hebdomadis were isolated from Zimbabwe cattle at slaughter. These isolates were subjected to cross-agglutinin absorption tests and to restriction fragment length polymorphism and pulsed-field gel electrophoresis analyses of their genomic DNAs. One of these strains represents a new serovar, for which the name mhou is proposed; strain SBF 40 is the reference strain of this serovar. The other three strains belong to a second new serovar, for which the name marondera is proposed; the reference strain of this serovar is strain SBF 5. The three strains of serovar marondera could be differentiated by their restriction fragment polymorphism and pulsed-field gel electrophoretic patterns.
\end{abstract}

Pathogenic Leptospira strains are currently divided into seven officially recognized species (Leptospira borgpetersenii, Leptospira inadai, Leptospira interrogans, Leptospira kirschneri, Leptospira noguchii, Leptospira santarosai, and Leptospira weilii) on the basis of the results of DNA-DNA hybridization studies (33, 42). The identification of a pathogenic strain as a member of one of these seven species is, however, insufficient for epidemiologists since it does not reflect any host-leptospire relationship. Furthermore, the techniques used for hybridization are still too complicated and not ideally suited for routine clinical laboratories, while phenotypic characteristics that have been proposed as characteristics which can be used to differentiate the seven species are limited and cannot be used for routine reliable identification. As a result, the serovar is still the recognized and generally accepted taxon for classification of members of the genus Leptospira at the subspecies level (23). Each serovar is represented by a reference strain to which its description is attached. "Two strains are said to belong to different serovars if after cross-absorption with adequate amounts of heterologous antigen, more than $10 \%$ of the homologous titer regularly remains in at least one of the two antisera in repeated tests" (23).

For practical purposes, strains belonging to separate but closely related serovars are grouped together into serogroups. The allocation of serovars into serogroups is essentially a consequence of the technique of serological typing and does not appear to have any other biological significance (23).

The serovar classification method used for leptospires is unsatisfactory because it is laborious and time consuming, requires maintenance of numerous reference strains and their corresponding rabbit immune sera and depends on an arbitrarily chosen numerical limit to distinguish serovars within a particular serogroup, which makes the method subjective and not reproducible. In addition, this method may delineate artificially closely related strains on the one hand while it fails to distinguish genetically different but antigenically similar strains

\footnotetext{
* Corresponding author. Mailing address: Department of Biological Sciences, University of Zimbabwe, MP 167, Mount Pleasant, Harare, Zimbabwe. Phone: 263-4-303211. Fax: 263-4-333407. Electronic mail address: feresu@zimbix.uz.zw.
}

on the other hand $(36,44)$. Furthermore, serological groups do not appear to corroborate DNA relatedness groups.

In an effort to replace the serological classification system with a natural subspecies classification system based on phylogenetically determined relationships, a variety of modern methods for genetic analysis have been introduced. These methods include chromosomal DNA restriction fragment length polymorphism (RFLP) analysis $(6,10,11,13,25,36)$, DNA hybridization with total DNA probes $(26,27,35)$, restriction analysis by Southern blotting with recombinant DNA probes $(24,28$, $37,41,43,44)$, restriction analysis of chromosomal DNA by pulsed-field gel electrophoresis (PFGE) (14-16), rRNA gene RFLP analysis $(17,19,29,30)$, and PCR fingerprinting (1a, 2, $12,18,31,32$ ). Although useful, these methods have so far failed to produce a coherent picture which allows researchers to develop a natural and logical classification system based on genetic traits. Moreover, the differences revealed by these methods have not yet been able to describe the desired host-leptospire relationships required for epidemiological studies.

Pending the development of a new classification system based on the new molecular typing methods, the International Committee on Systematic Bacteriology Subcommittee on the Taxonomy of Leptospira recommended that new field isolates should still be typed by the recognized standard method, the cross-agglutinin absorption test (CAAT), and given serovar status; however, other valid methods can be used for identification. The recommended methods include analysis with monoclonal antibodies or factor sera, analysis of RFLP or rRNA gene restriction fragment patterns, and PFGE analysis (21).

Pathogenic Leptospira strains are divided into more than 220 serovars, which are grouped into 23 serogroups (23). Until recently, the Hebdomadis serogroup was the largest and geographically most widespread of all serogroups. This serogroup became so large that some of its serovars showed very little serological relationship to one another. Using the factor analysis method, Kmety (22) proposed that this serogroup should be divided into three autonomous serogroups (the Hebdomadis, Mini, and Sejroe serogroups) on the basis of the distribution of main antigens. This proposal was adopted in 1982 (20). However, the members of these groups still exhibit clear intergroup relationships and cross-react during cross-agglutination tests. 
TABLE 1. CAAT results for Zimbabwe strains and antisera

\begin{tabular}{|c|c|c|c|c|c|c|}
\hline \multirow{3}{*}{ Antiserum } & \multirow{3}{*}{$\begin{array}{l}\text { Absorbing } \\
\text { strain }\end{array}$} & \multicolumn{4}{|c|}{ Reciprocal of titer } & \multirow{3}{*}{$\begin{array}{l}\text { Reciprocal of homologous } \\
\text { titer (\% of unabsorbed } \\
\text { serum titer) }\end{array}$} \\
\hline & & \multicolumn{2}{|c|}{ Before absorption } & \multicolumn{2}{|c|}{ After absorption } & \\
\hline & & Homologous strain & Absorbing strain & Homologous strain & Absorbing strain & \\
\hline SBF 5 & SBF 21 & 12,800 & 12,800 & 100 & 100 & 0.78 \\
\hline SBF 21 & SBF 5 & 6,400 & 6,400 & 100 & 100 & 1.56 \\
\hline SBF 5 & SBF 40 & 12,800 & 3,200 & 3,200 & 100 & 25 \\
\hline SBF 40 & SBF 5 & 6,400 & 3,200 & 800 & 100 & 12.5 \\
\hline SBF 5 & SBF 50 & 12,800 & 6,400 & 100 & 100 & 0.78 \\
\hline SBF 50 & SBF 5 & 12,800 & 12,800 & 400 & 100 & 3.125 \\
\hline SBF 21 & SBF 40 & 6,400 & 3,200 & 1,600 & 100 & 25 \\
\hline SBF 40 & SBF 21 & 3,200 & 3,200 & 800 & 100 & 25 \\
\hline SBF 21 & SBF 50 & 6,400 & 3,200 & 100 & 100 & 1.56 \\
\hline SBF 50 & SBF 21 & 12,800 & 6,400 & 100 & 100 & 0.78 \\
\hline SBF 40 & SBF 50 & 6,400 & 3,200 & 1,600 & 100 & 25 \\
\hline SBF 50 & SBF 40 & 6,400 & 3,200 & 1,600 & 100 & 25 \\
\hline
\end{tabular}

The new Hebdomadis serogroup contains 12 recognized serovars which are genetically very diverse and whose members fall into at least six genospecies ( $L$. borgpetersenii, $L$. interrogans, $L$. kirschneri, L. santarosai, $L$. weilii, and an unnamed genospecies) $(1,12,33,42)$. The majority of the reference strains of these serovars were initially isolated from humans (23). Only strain Bovino 131 of serovar goiano was isolated from the kidney of an apparently healthy cow in Brazil (34). The reference strains of serovars kabura, kambale, jules, and nona were first isolated from patients in Zaire (38-40). Serogroup Hebdomadis strains have also been isolated from humans in Kenya $(3,4)$.

The isolation and serogrouping of four strains belonging to serogroup Hebdomadis obtained from Zimbabwe cattle have been described previously (8). In this paper we describe identification of these strains to the serovar level, which was accomplished by performing CAAT, RFLP, and PFGE analyses of genomic DNA.

\section{MATERIALS AND METHODS}

Antisera from reference strains belonging to serogroup Hebdomadis serovars borincana, goiano, hebdomadis, jules, kabura, kambale, kremastos, longnan, manzhuang, maru, nona, sanmartini, and worsfoldi, serogroup Mini serovars beye, georgia, mini, perameles, ruparupae, szwajizak, and tabaquite, and serogroup Sejroe serovars balcanica, caribe, dikkeni, geyaweera, gorgas, guaricura, haemolytica, hardjo, istrica, medanensis, nyanza, polonica, recreo, nicardi, roumanica, saxkoebing, sejroe, trinidad, and wolffi and from the new isolates for use in the CAATs were produced in paired rabbits and pooled before use as described previously (9). The strains used are strains that are in the reference collections at the National Reference Laboratory at the National Disease Center (Ames, Iowa) and the World Health Organization/Food and Agriculture Organization Reference Laboratories at The Royal Tropical Institute (Amsterdam, The Netherlands) and Institut Pasteur (Paris, France).

The four serogroup Hebdomadis isolates obtained from Zimbabwe cattle were designated SBF 5, SBF 21, SBF 40, and SBF 50. These isolates and their antisera were tested in cross-agglutination tests against each other and against the serogroup Hebdomadis, Sejroe, and Mini reference strains and their antisera.

All of the isolates were cross-absorbed against each other's antisera, while only those reference strains which had a reciprocal titer of at least $1 / 1,600$ with isolates SBF 5, SBF 21, and SBF 50 and of 1/800 with isolate SBF 40 were used in CAATs. The CAATs were repeated three times by using the Bratislava technique (5) at the laboratory in Ames, Iowa, and the results were confirmed by workers at the Amsterdam laboratory.

The RFLP patterns of the four Zimbabwe strains were compared with the patterns of the serovar balcanica, beye, dikkeni, jules, kabura, kambale, man, medanensis, nona, perameles, saxkoebing, and worsfoldi reference strains. These serovars were selected on the basis of the results of the CAATs. Bacterial DNA extraction, restriction endonuclease digestion, gel electrophoresis, and photography were carried out as described by Thiermann et al. (36).

The DNA NotI restriction digestion products of all of the isolates were compared with the digestion products of all of the serogroup Hebdomadis serovar reference strains and the digestion products of serovar saxkoebing, balcanica, dikkeni (serogroup Sejroe), and perameles (serogroup Mini) reference strains by using PFGE. A restriction analysis in which PFGE was used was performed as described previously by Herrmann et al. (16).

\section{RESULTS}

High-level cross-agglutination reactions ( $>50 \%$ of the reciprocal titer of the homologous strain) were observed between the cattle isolates and several serogroup Hebdomadis, Sejroe, and Mini reference strains, indicating that strains SBF 5, SBF 21 , SBF 40 , and SBF 50 belonged to one of these three serogroups.

The results of CAATs performed with the Zimbabwean strains and antisera demonstrated that strains SBF 5, SBF 21, SBF 40, and SBF 50 belong to two serovars, one represented by strains SBF 5, SBF 21, and SBF 50 and the other represented by strain SBF 40 (Table 1).

Strain SBF 40 had titers higher than 1/1,600 with reference strains representing serovars kambale, maru, and nona (all serogroup Hebdomadis serovars) and higher than 1/800 with reference strains representing serovars medanensis and saxkoebing (both serogroup Sejroe serovars). The results of CAATs performed with strain SBF 40 and the reference strains indicate that although strain SBF 40 is closely related to serogroup Hebdomadis serovars, it is antigenically different from members of all previously described serovars of this serogroup because more than $10 \%$ of the antibodies remained in all of the paired antisera (Table 2). Therefore, on the basis of the current definition of a serovar, strain SBF 40 represents a new serovar in serogroup Hebdomadis.

Although CAATs were carried out with strains SBF 5, SBF 21 , and SBF 50 , only the results obtained for strain SBF 5, which cross-reacted with the largest number of reference strains of the serogroup Hebdomadis, Sejroe, and Mini serovars, are presented below. Therefore, strain SBF 5 was used as the reference strain for this subgroup. Strain SBF 5 was closely related to serovars jules, kabura, kambale, kremastos, maru, and nona (all serogroup Hebdomadis serovars), serovars beye and perameles (both serogroup Mini serovars), and serovars balcanica, dikkeni, and saxkoebing (all serogroup Sejroe serovars). Therefore, this strain was cross-absorbed with the reference strains of these serovars (Table 3). The results indicate that strain SBF 5 is most closely related to serogroup Hebdomadis strains but is antigenically distinct from members of all previously described serovars of this serogroup. Therefore, strains SBF 5, SBF 21, and SBF 50 represent a new serogroup Hebdomadis serovar. 
TABLE 2. Serovar identification of strain SBF 40 by CAAT

\begin{tabular}{|c|c|c|c|c|c|c|}
\hline \multirow{3}{*}{ Antiserum } & \multirow{3}{*}{$\begin{array}{l}\text { Absorbing strain } \\
\text { or serovar }\end{array}$} & \multicolumn{4}{|c|}{ Reciprocal of titer } & \multirow{3}{*}{$\begin{array}{l}\text { Reciprocal of homologous } \\
\text { titer (\% of unabsorbed } \\
\text { serum titer) }\end{array}$} \\
\hline & & \multicolumn{2}{|c|}{ Before absorption } & \multicolumn{2}{|c|}{ After absorption } & \\
\hline & & Homologous strain & Absorbing strain & Homologous strain & Absorbing strain & \\
\hline SBF 40 & kambale & 3,200 & 3,200 & 800 & 0 & 25 \\
\hline kambale & SBF 40 & 12,800 & 1,600 & 6,400 & 200 & 50 \\
\hline SBF 40 & maru & 3,200 & 1,600 & 1,600 & 0 & 50 \\
\hline maru & SBF 40 & 25,600 & 1,600 & 12,800 & 200 & 50 \\
\hline SBF 40 & nona & 3,200 & 3,200 & 1,600 & 100 & 50 \\
\hline nona & SBF 40 & 12,800 & 3,200 & 6,400 & 200 & 50 \\
\hline SBF 40 & medanensis & 3,200 & 1,600 & 1,600 & 0 & 50 \\
\hline medanensis & SBF 40 & 12,800 & 800 & 25,600 & 0 & 200 \\
\hline SBF 40 & saxkoebing & 3,200 & 800 & 3,200 & 0 & 100 \\
\hline saxkoebing & SBF 40 & 12,800 & 800 & 6,400 & 0 & 50 \\
\hline
\end{tabular}

Strains SBF 5 and SBF 21 had identical RFLP patterns when they were digested with endonucleases HhaI (Fig. 1) and EcoRI (data not shown). Strain SBF 50 had a slightly different pattern; it lacked several fragments in the 4.5 - to 5.6-kb size range. Although strain SBF 40 shared some bands with strains SBF 5, SBF 21, and SBF 50, its RFLP pattern was more distinct.

All of the cattle strains had patterns which were different from the patterns of all of the reference strains.

The PFGE results are shown in Fig. 2. Although isolates SBF 5, SBF 21, and SBF 50 had similar PFGE patterns, the restriction patterns of strains SBF 21 and SBF 50 had two fragments, one $140 \mathrm{~kb}$ long and the other $320 \mathrm{~kb}$ long, which were not present in the restriction pattern of strain SBF 5. In addition, the patterns of strains SBF 5 and SBF 21 had a similar largest fragment (length, $>500 \mathrm{~kb}$ ) which was not pres- ent in the strain SBF 50 pattern. Instead, the largest fragment in the strain SBF 50 pattern was approximately $400 \mathrm{~kb}$ long.

Strain SBF 40 had a unique profile which was different from the profiles of the other three cattle isolates.

The PFGE restriction patterns obtained for strains SBF 5, SBF 21, SBF 40, and SBF 50 were quite different from the patterns obtained for most of the serogroup Hebdomadis serovars, including serovarsborincana, goiano, hebdomadis, kambale, kremastos, sanmartini, and worsfoldi, the patterns obtained for serogroup Sejroe serovars balcanica, dikkeni, and saxkoebing, and the pattern obtained for serogroup Mini serovar perameles (data not shown), but had several fragments in common with the patterns obtained for serogroup Hebdomadis serovars kabura, jules, maru, and nona (Fig. 2). The restriction patterns of strains SBF 5, SBF 21, SBF 40, and SBF 50 were most similar to those of serovars jules and nona.

TABLE 3. Serovar identification of strain SBF 5 by CAAT

\begin{tabular}{|c|c|c|c|c|c|c|}
\hline \multirow{3}{*}{ Antiserum } & \multirow{3}{*}{$\begin{array}{l}\text { Absorbing strain } \\
\text { or serovar }\end{array}$} & \multicolumn{4}{|c|}{ Reciprocal of titer } & \multirow{3}{*}{$\begin{array}{c}\text { Reciprocal of homologous } \\
\text { titer (\% of unabsorbed } \\
\text { serum titer) }\end{array}$} \\
\hline & & \multicolumn{2}{|c|}{ Before absorption } & \multicolumn{2}{|c|}{ After absorption } & \\
\hline & & Homologous strain & Absorbing strain & Homologous strain & Absorbing strain & \\
\hline SBF 5 & jules & 12,800 & 3,200 & 6,400 & 100 & 50 \\
\hline jules & SBF 5 & 6,400 & 1,600 & 3,200 & 100 & 50 \\
\hline SBF 5 & kabura & 12,800 & 3,200 & 6,400 & 200 & 50 \\
\hline kabura & SBF 5 & 6,400 & 3,200 & 3,200 & 100 & 50 \\
\hline SBF 5 & kambale & 12,800 & 3,200 & 800 & 0 & 6.25 \\
\hline kambale & SBF 5 & 12,800 & 6,400 & 6,400 & 400 & 50 \\
\hline SBF 5 & kremastos & 12,800 & 1,600 & 6,400 & 0 & 50 \\
\hline kremastos & SBF 5 & 12,800 & 3,200 & 6,400 & 200 & 50 \\
\hline SBF 5 & maru & 12,800 & 6,400 & 3,200 & 200 & 25 \\
\hline maru & SBF 5 & 51,200 & 12,800 & 6,400 & 400 & 12.5 \\
\hline SBF 5 & nona & 12,800 & 6,400 & 6,400 & 400 & 50 \\
\hline nona & SBF 5 & 12,800 & 6,400 & 12,800 & 200 & 100 \\
\hline SBF 5 & beye & 12,800 & 1,600 & 12,800 & 200 & 100 \\
\hline beye & SBF 5 & 12,800 & 1,600 & 6,400 & 200 & 50 \\
\hline SBF 5 & perameles & 12,800 & 1,600 & 6,400 & 100 & 50 \\
\hline perameles & SBF 5 & 12,800 & 3,200 & 12,800 & 200 & 100 \\
\hline SBF 5 & balcanica & 12,800 & 1,600 & 6,400 & 0 & 50 \\
\hline balcanica & SBF 5 & 6,400 & 1,600 & 6,400 & 100 & 100 \\
\hline SBF 5 & dikkeni & 12,800 & 1,600 & 6,400 & 400 & 50 \\
\hline dikkeni & SBF 5 & 6,400 & 1,600 & 3,200 & 200 & 50 \\
\hline SBF 5 & saxkoebing & 12,800 & 3,200 & 6,400 & 0 & 50 \\
\hline saxkoebing & SBF 5 & 12,800 & 3,200 & 6,400 & 100 & 50 \\
\hline
\end{tabular}




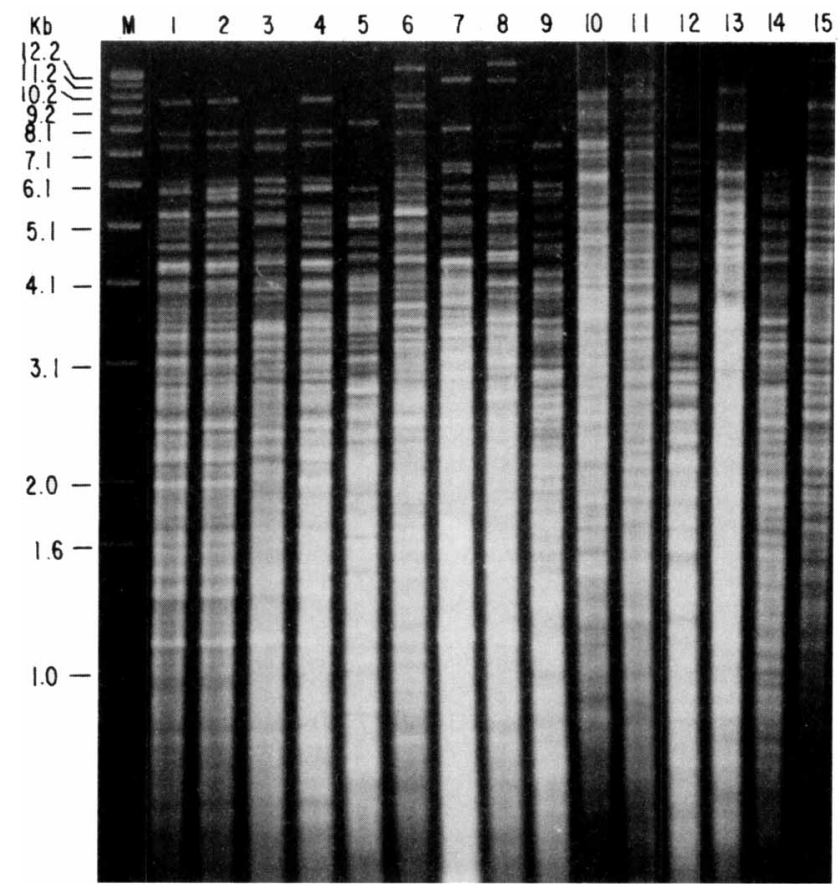

FIG. 1. RPLP patterns for chromosomal DNAs from four Zimbabwe isolates and serogroup Hebdomadis, Mini, and Sejroe reference strains digested with HhaI. Lane M, fragment size markers; lane 1, strain SBF 5; lane 2, strain SBF 21; lane 3, strain SBF 40; lane 4, strain SBF 50; lanes 5 to 15 , reference strains belonging to serovars maru, nona, balcanica, dikkeni, beye, perameles, kabura, worsfoldi, saxkoebing, jules, and medanensis, respectively.

\section{DISCUSSION}

Identification of serovars is necessary for epidemiological surveillance since some serovars are known to have preferential animal reservoirs (e.g., serovar icterohaemorrhagiae occurs in rats, serovar canicola occurs in dogs, and serovar hardjo occurs in bovines) or are associated with certain clinical forms (e.g., serovar icterohaemorrhagiae is associated with icterogenic syndrome and serovar grippotyphosa is associated with benign meningitis syndrome) (7). Thus, our choice of methods (RFLP analysis of chromosomal DNA and PFGE analysis of NotI genomic DNA restriction digestion products) was biased as the data obtained with both of these methods largely support the serovar concept (13-16). In addition, both of these methods allow workers to differentiate strains of the same serovar, which usually correlates with differences in the epidemiology of strains and possibly the pathogenicity of strains $(6,16)$. Thus, the two methods serve as supplementary typing systems in epidemiological studies.

Another advantage of using RFLP analysis is that most reference strains have already been examined by this method and the bulk of the information is readily available for comparison. PFGE is a complementary method which has the advantage of using larger DNA fragments, thus producing simpler patterns which are easier to interpret $(15,16)$. Some serovars, however, have similar RFLP and PFGE patterns and are not easily differentiated by these two methods alone $(15,36,44)$.

Using three methods, we identified two new serovars in serogroup Hebdomadis which are antigenically and genetically different from all previously described serogroup Hebdomadis serovars. The name mhou is proposed for the new serovar represented by strain SBF 40, which also has distinct RFLP and PFGE restriction patterns, and the name marondera is

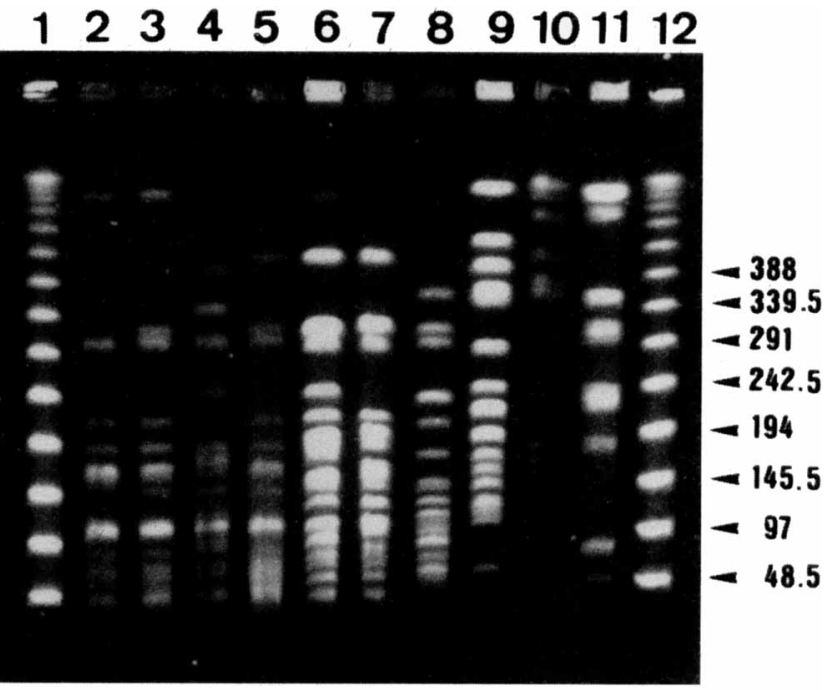

FIG. 2. PFGE of NotI restriction fragments from four Zimbabwe isolates and serogroup Hebdomadis reference strains. The digestion products were separated by electrophoresis at $150 \mathrm{~V}$ for $25 \mathrm{~h}$ in $1 \%$ agarose- $0.5 \times$ Tris-borate-EDTA with a CHEF DR-II apparatus (Bio-Rad Laboratories, Richmond, Calif.). The pulse times consisted of a ramping program from 5 to $40 \mathrm{~s}$. Lanes 1 and 12, lambda concatemer size markers; lane 2, strain SBF 5; lane 3, strain SBF 21; lane 4, strain SBF 40; lane 5, strain SBF 50; lanes 6 to 11, reference strains belonging to serovars nona, jules, maru, kabura, hebdomadis, and kremastos, respectively.

proposed for the second new serovar; strain SBF 5 is the reference strain of serovar marondera. Within serovar marondera we were able to demonstrate that there are three genetic types, represented by isolates SBF $5, \mathrm{SBF} 21$, and SBF 50.

We believe that all of the isolates which we examined have now been characterized sufficiently so that they can be designated members of new serovars but concede that the methods used for our classification do not reflect the species affiliation of the new strains. The strains have been deposited in the Amsterdam and Paris world reference collections and are available to other researchers for species identification.

An interesting observation is the similarity between the PFGE patterns of our isolates and the patterns of reference strains of serovars jules and nona, which are also of African origin.

The results of this study once again highlight the existence of many as-yet-undiscovered Leptospira types on the African continent.

\section{ACKNOWLEDGMENTS}

We thank Annette Handsaker and John Foley for technical assistance and I. Saint Girons for advice on PFGE analyses.

Isolation work was financed by grants from the University of Zimbabwe Research Board and the International Foundation for Science. S.B.F. was sponsored by Fogarty USA Public Health Service International research fellowship IF 05 TW 4154-01.

\section{REFERENCES}

1. Brenner, D. J. Personal communication.

1a.Corney, B. G., J. Colley, S. P. Djordjevic, R. Whittington, and G. C. Graham. 1993. Rapid identification of some Leptospira isolates from cattle by random amplified polymorphic DNA fingerprinting. J. Clin. Microbiol. 31:2927-2932.

2. De Caballero, O. L. S. D., E. D. Neto, M. C. Koury, A. J. Romanha, and A. J. G. Simpson. 1994. Low-stringency PCR with diagnostically useful primers for identification of Leptospira serovars. J. Clin. Microbiol. 32:1369-1372.

3. De Geus, A., J. W. Wolff, and V. E. A. Timmer. 1977. Clinical leptospirosis in Kenya (I): a clinical study in Kwale District, Coast Province. East Afr. Med. J. 54:115-124.

4. De Geus, A., J. W. Wolff, and V. E. A. Timmer. 1977. Clinical leptospirosis in Kenya (II): a field study in Nyanza Province. East Afr. Med. J. 54:125-132. 
5. Dikken, H., and E. Kmety. 1978. Serological typing methods of leptospires. Methods Microbiol. 11:259-307.

6. Ellis, W. A., J. M. Montgomery, and A. B. Thiermann. 1991. Restriction endonuclease analysis as a taxonomic tool in the study of pig isolates belonging to the Australis serogroup of Leptospira interrogans. J. Clin. Microbiol. 29:957-961.

7. Faine, S. 1982. Guidelines for leptospirosis control. WHO Offset Publ. 67: 43-66.

8. Feresu, S. B. 1992. Isolation of Leptospira interrogans from kidneys of Zimbabwe beef cattle. Vet. Rec. 130:446-448.

9. Feresu, S. B., and C. A. Bolin. 1991. Characterization of Leptospira interrogans isolated from cattle in Zimbabwe, p. 215-224. In Y. Kobayashi (ed.), Leptospirosis. Proceedings of the Leptospirosis Research Conference 1990. University of Tokyo Press, Tokyo.

10. Feresu, S. B., C. A. Bolin, and H. Korver. 1993. A new leptospiral serovar in the Icterohaemorrhagiae serogroup isolated from an ox in Zimbabwe. Int. J. Syst. Bacteriol. 43:179-182.

11. Feresu, S. B., C. A. Bolin, H. Korver, and W. J. Terpstra. 1994. Classification of leptospires of the Pyrogenes serogroup isolated from cattle in Zimbabwe by cross-agglutinin absorption and restriction fragment length polymorphism analysis. Int. J. Syst. Bacteriol. 44:541-546.

12. Gravekamp, C., H. Van De Kemp, M. Franzen, D. Carrington, G. J. Schoone, G. J. J. M. Van Eys, C. O. R. Everard, R. A. Hartskeerl, and W. J. Terpstra. 1993. Detection of seven species of pathogenic leptospires by PCR using two sets of primers. J. Gen. Microbiol. 139:1691-1700.

13. Hathaway, S. C., R. B. Marshall, T. W. A. Little, S. A. Headlam, and P. J. Winter. 1985. Differentiation of reference strains of leptospires of the Pomona serogroup by cross-agglutination absorption and restriction endonuclease analysis. Res. Vet. Sci. 39:145-150.

14. Herrmann, J. L., P. Bakoss, H. Korver, A. A. Bulu, E. Bellenger, W. J. Terpstra, I. Saint Girons, and G. Baranton. 1994. A new serovar in the Grippotyphosa serogroup comprising leptospiral isolates from different regions. Int. J. Syst. Bacteriol. 44:362-364.

15. Herrmann, J. L., C. Baril, E. Bellenger, P. Perolat, G. Baranton, and I. Saint Girons. 1991. Genome conservation in isolates of Leptospira interrogans. J. Bacteriol. 173:7582-7588.

16. Herrmann, J. L., E. Bellenger, P. Perolat, G. Baranton, and I. Saint Girons. 1992. Pulsed-field gel electrophoresis of NotI digests of leptospiral DNA: a new rapid method of serovar identification. J. Clin. Microbiol. 30:1696-1702

17. Hookey, J. V. 1990. The detection of genetic variation in Leptospira interrogans serogroup Icterohaemorrhagiae by ribosomal RNA gene restriction fragment patterns. FEMS Microbiol. Lett. 72:329-336.

18. Hookey, J. V. 1992. Detection of Leptospiraceae by amplification of $16 \mathrm{~S}$ ribosomal DNA. FEMS Microbiol. Lett. 90:267-274.

19. Hookey, J. V. 1993. Characterization of Leptospiraceae by 16 S DNA restriction fragment length polymorphisms. J. Gen. Microbiol. 139:1681-1689.

20. International Committee on Systematic Bacteriology Subcommittee on the Taxonomy of Leptospira. 1984. Minutes of the meeting, 6 to 10 August 1982, Boston, Mass. Int. J. Syst. Bacteriol. 34:258-259.

21. International Committee on Systematic Bacteriology Subcommittee on the Taxonomy of Leptospira. 1995. Minutes of the meetings, 1 and 2 July 1994 , Prague, Czech Republic. Int. J. Syst. Bacteriol. 45:872-874.

22. Kmety, E. 1977. Study of the antigenic structure of the leptospirae. Classification of the serological group Hebdomadis. Folia Fac. Med. Univ. Comenianae Bratisl. 15:245-251.

23. Kmety, E., and H. Dikken. 1993. Classification of the species Leptospira interrogans and history of its serovars. University Press, Gronigen, The Netherlands.

24. LeFebvre, R. B. 1987. DNA probe for detection of the Leptospira interrogans serovar hardjo genotype Hardjo-bovis. J. Clin. Microbiol. 25:2236-2238.

25. Marshall, R. B., B. E. Wilton, and A. J. Robinson. 1981. Identification of leptospira serovars by restriction-endonuclease analysis. J. Med. Microbiol. 14:163-166.
26. Millar, B. D., R. J. Chappel, and B. Alder. 1987. Detection of leptospires in biological fluids using DNA hybridisation. Vet. Microbiol. 15:71-78.

27. Nielsen, J. N., C. H. Armstrong, and N. C. Nielsen. 1989. Relationship among selected Leptospira interrogans serogroups as determined by nucleic acid hybridization. J. Clin. Microbiol. 27:2724-2729.

28. Pacciarini, M. L., M. L. Savio, S. Tagliabue, and C. Rossi. 1992. Repetitive sequences cloned from Leptospira interrogans serovar hardjo genotype Hardjoprajitno and their application to serovar identification. J. Clin. Microbiol. 30:1243-1249.

29. Pérolat, P., F. Grimont, B. Regnault, P. A. D. Grimont, E. Fournié, H. Thevenet, and G. Baranton. 1990. rRNA gene restriction patterns of Leptospira: a molecular typing system. Res. Microbiol. 141:159-171.

30. Perolat, P., I. Lecuyer, D. Postic, and G. Baranton. 1993. Diversity of ribosomal DNA fingerprints of Leptospira serovars provides a database for subtyping and species assignation. Res. Microbiol. 144:5-15.

31. Perolat, P., F. Merien, W. A. Ellis, and G. Baranton. 1994. Characterization of Leptospira isolates from serovar hardjo by ribotyping, arbitrarily primed PCR, and mapped restriction site polymorphisms. J. Clin. Microbiol. 32: 1949-1957.

32. Ralph, D., M. McClelland, J. Welsh, G. Baranton, and P. Perolat. 1993 Leptospira species categorized by arbitrarily primed polymerase chain reaction (PCR) and by mapped restriction polymorphisms in PCR-amplified rRNA genes. J. Bacteriol. 175:973-981.

33. Ramadass, P., B. D. W. Jarvis, R. J. Corner, D. Penny, and R. B. Marshall. 1992. Genetic characterization of pathogenic Leptospira species by DNA hybridization. Int. J. Syst. Bacteriol. 42:215-219.

34. Santa Rosa, C. A., C. R. Sulzer, A. F. Pestana de Castro, R. M. Yanaguita, and W. Giorgi. 1980. Two new leptospiral serovars in the Hebdomadis group isolated from cattle in Brazil. Int. J. Zoonoses 7:158-163.

35. Terpstra, W. J., G. J. Schoone, G. S. Ligthart, and J. Ter Schegget. 1987. Detection of Leptospira interrogans in clinical specimens by in situ hybridization using biotin-labelled DNA probes. J. Gen. Microbiol. 133:911-914.

36. Thiermann, A. B., A. L. Handsaker, J. W. Foley, F. H. White, and B. F. Kingscote. 1986. Reclassification of North American leptospiral isolates belonging to serogroups Mini and Sejroe by restriction endonuclease analysis. Am. J. Vet. Res. 47:61-66.

37. Van Eys, G. J. J. M., M. J. Gerritsen, H. Korver, G. J. Schoone, C. C. M. Kroon, and W. J. Terpstra. 1991. Characterization of serovars of the genus Leptospira by DNA hybridization with Hardjobovis and Icterohaemorrhagiae recombinant probes with special attention to serogroup Sejroe. J. Clin. Microbiol. 29:1042-1048.

38. Van Riel, J. 1952. Sur l'existence au Congo Belge d'un leptospire du groupe Hebdomadis. Ann. Soc. Belge Med. Trop. 32:683-691.

39. Van Riel, J., L. Szpaishaendler, and M. Van Riel. 1956. Etude clinique, bacteriologique et èpidèmiologique d'un nouveau foyer de leptospirose au Congo Belge. Bull. Soc. Pathol. Exot. 49:118-143.

40. Van Riel, J., and M. Van Riel. 1960. Analyse antigénique de six souches du sérogroup Leptospira hebdomadis. Ann. Soc. Belge Med. Trop. 40:449-560.

41. Woodward, M. J., and G. J. Sullivan. 1991. Nucleotide sequence of a repetitive element isolated from Leptospira interrogans serovar hardjo type Hardjo-bovis. J. Gen. Microbiol. 137:1101-1109.

42. Yasuda, P. H., A. G. Steigerwalt, K. R. Sulzer, A. F. Kaufmann, F. Rogers, and D. J. Brenner. 1987. Deoxyribonucleic acid relatedness between serogroups and serovars in the family Leptospiraceae with proposals for seven new Leptospira species. Int. J. Syst. Bacteriol. 37:407-415.

43. Zuerner, R. L., and C. A. Bolin. 1988. Repetitive sequence element cloned from Leptospira interrogans serovar hardjo type Hardjo-bovis provides a sensitive diagnostic probe for bovine leptospirosis. J. Clin. Microbiol. 26: 2495-2500.

44. Zuerner, R. L., and C. A. Bolin. 1990. Nucleic acid probe characterizes Leptospira interrogans serovars by restriction fragment length polymorphisms. Vet. Microbiol. 24:355-366. 